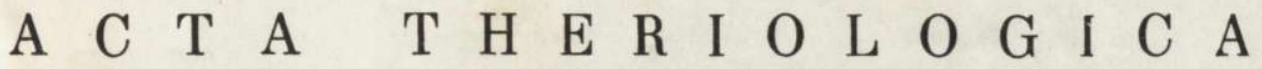 \\ VOL. XVI, 4: 73-78. \\ BIAEOWIEŻA \\ April, 1971
}

Anna K A L I N O W S K A

\section{Trapping of Apodemus flavicollis and Clethrionomys glareolus into a Double Trap}

[With 2 Tables \& 1 Fig.]

\begin{abstract}
The experiment carried out on Clethrionomys glareolus ( $\mathrm{S} \mathrm{ch} \mathrm{reber,}$ 1780) and Apodemus flavicollis ( $\mathrm{Mel} \mathrm{ch}$ ior, 1834) with double traps showed significant differences in the percentage of captures of each species depending on the content of one part of a trap. The lowest percentage of captures for both species was recorded when the trap contained initially an individual of A. flavicollis. On the other hand the percentage of captures of A. flavicollis was found almost the same for empty traps and for traps containing C. glareolus. The latter species was captured more often into traps with an individual of the same species than into empty traps.
\end{abstract}

\section{INTRODUCTION}

Relationships between populations of two species of forest rodents Clethrionomys glareolus (S ch rebe r, 1780) and Apodemus flavicollis (M e l c h i o r, 1834) are aggressive (N a u mov, 1948; G ol ik ova, 1957; Turček, 1960; Andrzejewski \& Olszewski, 1963 a,b).

A basic method of investigation of these species depends on trapping them with various traps. For intensification of captures in some cases "multiple« traps are used allowing capture of several animals into one container.

A question arises whether aggressive relationships between these species exert an effect on the capture of a second individual into a double trap. When expanding this problem one can ask whether multiple traps containing already one captured individual may be used for studying relationships between some species. 
The experiment was carried out with a live trap permitting capture of a second individual into a cage containing already one animal. Such trap consists of two identical and independently shutting parts. Each of them includes a house and a run. These runs, made of wire net, enable a partial contact of an animal with surroundings and the neighbouring part of the trap (Fig. 1).

In the first stage of the experiment 100 stands of prebaiting were set in linear order with distances between neighbouring stands amounting to approximately $15 \mathrm{~m}$. The oat was used as a bait supplemented every day. The traps were divided into three groups depending on the host animal: a) contained C. glareolus in one part of the trap, b) contained A. flavicollis, c) was left empty, with only one part of the trap set. In all cases the two parts of the trap contained (as food or bait)

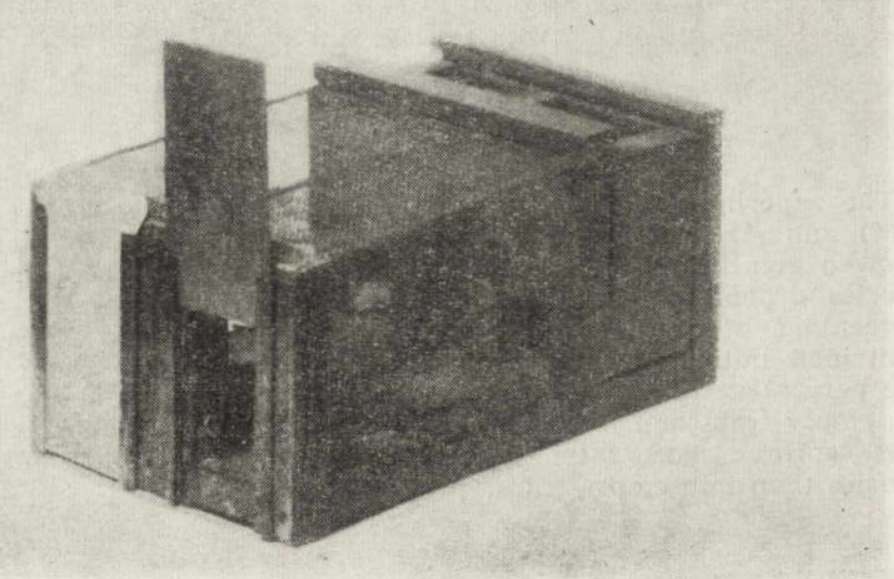

Fig. 1. Double trap used in experiments.

grains of oats, clover and apple slices. The traps were inspected twice a day morning and evening. It was intended to change at every inspection the place of setting and type of trap according to the following assumptions:

1. In a place where no capture was observed during two consecutive inspections the host animal was changed. After four failures the stand was liquidated.

2. A rodent trapped in a given place was transferred to another stand as the host of a newly set trap.

3. An attempt was made to ensure rotation of traps during consecutive inspections in all stands where the bait was consumed.

In the studied area the population density of C. glareolus was much higher than A. flavicollis. For this reason the ratio of empty traps, traps with A. flavicollis and traps with $C$. glareolus was suitably adapted as $2: 1: 2$. To maintain the same ratio despite irregular trapping of animals on the experimental plot some rodents placed in cages as hosts derived from extra traps set in another area. The experiment was carried out between 15 August and 15 November 1968.

After rejecting cases when shutting the cage was caused by other reasons than capture of a rodent (rain, trapping of birds), or when the cage was not shut despite 
consumed bait, 2584 settings of traps was taken into analysis (Table 1). Altogether 671 rodents were captured into double traps during the experiment. The number of captures in each type of traps was compared with a theoretical number calculated in proportion to quantity of each type of traps (Table 2).

\section{DESCRIPTION OF THE STUDIED AREA}

The investigations were carried out in two series. The first one was accomplished in an area of mixed wood classified as Pino-Quercetum ( $\mathrm{K} \mathrm{oz} \mathrm{low} \mathrm{s} \mathrm{k} \mathrm{a,} \mathrm{1925)}$ in the forest district Sniardwy $\left(\lambda=21^{\circ} 40^{\prime} \mathrm{E}, \varphi=53^{\circ} 50^{\prime} \mathrm{N}\right)$. The second series was carried out on an experimental plot belonging to the Institute of Ecology PAN near Dziekanów Leśny $\left(\lambda=20^{\circ} 30^{\prime} \mathrm{E}, \varphi=52^{\circ} 15^{\prime} \mathrm{N}\right)$ in the Kampinos Primaeval Forest within the Vaccinio myrtilli-Pinetum association ( $\mathrm{K} \circ \mathrm{bendza}, 1930$ ). In these two plots rather thick undergrowth and layer of bedding created favourable conditions for rodent life. The obtained results were analysed jointly.

\section{ANALYSIS OF THE MATERIAL AND DISCUSSION}

The results of the experiment were expressed in per cents by calculating the number of captured individuals of each species per one hundred

Table 1

Number of settings of each trap type and results of trapping in comparison with the theoretical number of captures calculated after assumption that rodents are captured in proportion to the number of set traps independently of their type.

\begin{tabular}{|l|c|c|c|c|c|}
\hline \multirow{2}{*}{ Trap type } & $\begin{array}{c}\text { No. of } \\
\text { set traps }\end{array}$ & $\begin{array}{c}\text { C. glareolus } \\
\text { No. of } \\
\text { captured } \\
\text { rodents }\end{array}$ & $\begin{array}{c}\text { Theoretical } \\
\text { no. of } \\
\text { captures }\end{array}$ & $\begin{array}{c}\text { A. flavicollis } \\
\text { captured } \\
\text { rodents }\end{array}$ & $\begin{array}{c}\text { Theoretical } \\
\text { no. of } \\
\text { captures }\end{array}$ \\
\hline Empty & 1071 & 281 & 268 & 139 & 112 \\
With A. flavicollis & 496 & 52 & 134 & 22 & $\vdots$ \\
With C. glareolus & 1017 & 338 & 268 & 120 & 112 \\
Total & 2584 & 671 & 671 & 281 & 281 \\
\hline
\end{tabular}

of settings of appropriate type of traps. The columns in Table 2 read vertically show the percentage share of each species in the filling of a given type of traps, and when read horizontally allow to compare the percentage of individuals of each species captured into corresponding types of traps. The arrows illustrate statistically significant differences (evaluated by Student's $t$-test at the level $\mu=0.95$ ) between percentage of trapping in relation to the number of set traps.

There is no statistical difference between the percentage of captures of A. flavicollis into empty traps and those containing C. glareolus $(P>0.05)$. In all the remaining cases the differences are significant 
$(P<0.001)$. Large differences in the number of captures depending on the host animal indicate that the rodent in the cage with the net confined run exerts some influence on individuals of $C$. glareolus and A. flavicollis penetrating the area in the trap vicinity and elicits their various reactions.

Environmental and alimentary requirements of these two species are similar. In areas inhabited both by $C$. glareolus and A. flavicollis individuals of the former species are often driven out to less favourable surroundings ( $\mathrm{N} \mathrm{a} \mathrm{u} \mathrm{mov,} \mathrm{1948;} \mathrm{Golikova,} \mathrm{1957).} \mathrm{Investigations}$ carried out by means of noctovision demonstrated that when individuals of these two species meet each other $C$. glareolus is driven out from the vicinity of A. flavicollis (Andrzejewski \& Olszewski, 1963). It can be thus assumed that the two species compete but $A$. flavicollis rather dominates and the results of the trapping experiment should be also interpreted on this plane.

Table 2

Percentage share of each species in the filling of trap of a given type and comparison of percentage of individuals of each species captured into each type of traps.

\begin{tabular}{|c|c|c|c|}
\hline \multirow{2}{*}{ Captures } & \multirow{2}{*}{ Empty } & \multicolumn{2}{|c|}{ Settings } \\
\hline & & With A. flavicollis & With C. glareolus \\
\hline & & & \\
\hline No. capture & $61 \%$ & $85_{\%}^{o}-$ & $\rightarrow 55 \%$ \\
\hline A. flavicollis & $13_{\%}^{\sigma}-$ & $\longrightarrow 4.5 \% \leftarrow$ & $-12 \%$ \\
\hline C. glareolus & $26_{\%}^{o}-$ & $\longrightarrow 10.5_{\%}^{o} \leftarrow$ & $-33 \%$ \\
\hline
\end{tabular}

The lowest percentage of captures for both species was recorded in traps containing initially $A$. flavicollis. It may be assumed that $A$. flavicollis acts deterringly on other individuals of the same species or of C. glareolus. The percentage of captures of $C$. glareolus is even lower than A. flavicollis and this indicates the occurrence of a definite reaction to A. flavicollis and not only mechanical frightening of all individuals in the trap vicinity. It is known that in case of intensive penetration of A. flavicollis in any area C. glareolus shifts its activity to daily hours or avoids in time or space points occupied by the former species (A ndrzejewski \& Olszewski, 1963b). 
From the analysis of captures of A. flavicollis and C. glareolus plotted on a map it arises that $C$. glareolus appears only occasionally in places where previously A. flavicollis was captured ( $\mathrm{T}$ u r č ek, 1960). The low percentage of captures into traps containing A. flavicollis may be thus explained by the avoidance of these places by $C$. glareolus.

A rather small number of captures of A. flavicollis into traps containing individuals of the same species is difficult to explain. Perhaps conditions in the cage cause changes in the behaviour of confined animals, or aggressive individuals of this species generally avoid each other.

There is no significant difference in the percentage of captures of A. flavicollis into empty traps and traps containing C. glareolus. This fact indicates that the presence of $C$. glareolus has no effect on the penetration of a trap by $A$. flavicollis. In other words the presence of a subdominant exerts no influence on behaviour of a dominant.

In the case of $C$. glareolus exists a marked predominance of captures into traps with an individual of the same species in comparison with empty traps. This may indicate developed social bonds between individuals of this species. Andrzejewski \& Olszewski (1963) suggested that driving out of C. glareolus by A. flavicollis causes an increased number of meetings of individuals of the former species. This leads to reduction of tolerant meetings and increase of aggressive ones. When it is assumed that individuals of C. glareolus penetrating the area around a trap aim at aggressive meetings it may be supposed that they defend their own district or occupy a higher position in social hierarchy.

It is difficult to define to what degree the reciprocal influence of individuals of these two species is deformed by the reaction to trap of a confined animal, and whether species differences in sensory reactions provide for both species an equal chance of perception of a confined individual.

Acknowledgements: The author wishes to express sincere thanks to Professor K. Petrusewicz for offering facilities for this study in the Institute of Ecology, and to Dr. R. Andrzejewski for guidance and help in elaborating the results.

\section{REFERENCES}

1. Andrzejewski R. \& Olszewski J., 1963a: Noktowizja jako metoda badań ekologicznych drobnych ssaków. Ekol. pol., B 9, 4: 313-320.

2. Andrzejewski R. \& Olszewski J., 1963b: Social behaviour and interspecific relations in Apodemus flavicollis (M elchior, 1834), and Clethrionomys glareolus (S chreber, 1780). Acta theriol., 7, 10: 155-168.

3. Golikova V. L., 1957: Vlijanie mežvidovyh otnošenij na rasprostranenie lesnyh myševidnyh gryzunov vnutri areala. Izd. Lvovskovo Univ.: 1-71. Lvov. 
4. N a u mov N. P., 1948: Očerki sravnitelnoj ekologii myševidnyh gryzunov. Sovietskaja Nauka: 1-204. Moskva-Leningrad.

5. Turček F. J., 1960: Sidelne vstahy niektorých drobných lesných hlodavcov zistené na podklade mapovania. Biologia, 15, 10: 729-736.

Accepted, August 12, 1970.

Department of Animal Ecology,

Institute of Zoology,

Warsaw University,

Warszawa, Nowy Swiat 67.

Anna KALINOWSKA

ŁOWIENIE SIE APODEMUS FLAVICOLLIS I CLETHRIONOMYS GLAREOLUS DO PODWÓJNEJ PUŁAPKI

Streszczenie

Literatura dotycząca Apodemus flavicollis (Melchior, 1834) i Clethrionomys glareolus (S chreber, 1780) wskazuje na agresywność stosunków między tymi gatunkami. W związku z tym nasuwa się pytanie czy pierwszy złowiony do pułapki wielołownej osobnik jednego $\mathrm{z}$ tych gatunków ma wpływ na połów dalszych osobników tego samego a także drugiego gatunku. Przeprowadzony eksperyment miał na celu odpowiedzieć na powyższe pytanie a tym samym sprawdzić, czy pulapki wielołowne posiadające już złowionego osobnika mogą być przydatne do badania stosunków między gatunkami.

Eksperyment przeprowadzono w dwu zbiorowiskach borowych przy pomocy pułapek dwułownych (Ryc. 1) składających się z dwu niezależnie od siebie zamykających się części, dzieląc je, zależnie od zagospodarowania jednej z tych części, na trzy typy: a) puste (nastawiona tylko jedna połowa), b) z A. flavicollis, c) z C. glareolus. Wyniki doświadczenia (Tab. 1) przedstawiono w procentach obliczając liczbę zlowień osobników każdego $\mathrm{z}$ gatunków na sto nastawień każdego $\mathrm{z}$ typów pulapek (Tab. 2). Z porównania tych procentów wynika, że: 1) najniższy procent złowień notuje się $\mathrm{w}$ pułapkach $\mathrm{z}$ zamkniętą myszą leśną i to zarówno osobników tego samego gatunku jak i nornic. 2) Procent złowień myszy leśnych do pułapek pustych i pułapek z nornicą jest prawie równy, natomiast nornice znacznie częściej łowią się do pułapek $\mathrm{z}$ osobnikiem swego gatunku niż do pułapek pustych. Statystycznie istotne różnice $\mathrm{w}$ ilości zlowień w zależności od gospodarza pułapki wskazują, że gryzoń w klatce oddziaływuje na osobniki penetrujące teren w pobliżu, wywolując ich różne w zależności od gatunku reakcje. 